\title{
PENINGKATAN KAPASITAS PRODUKSI UMKM ARANG KAYU JEPARA
}

\author{
Silviana Pebruary ${ }^{1}$, Eko Nur Fuad ${ }^{2}$, Samsul Arifin ${ }^{3}$, Musyafa $^{4}$ \\ ${ }^{1}$ Program Studi Ekonomi Islam, Fakultas Ekonomi dan Bisnis, Universitas Islam Nahdlatul Ulama Jepara \\ Jl. Taman Siswa (Pekeng) Tahunan Jepara 59427 \\ ${ }^{2}$ Program Studi Manajemen, Fakultas Ekonomi dan Bisnis, Universitas Islam Nahdlatul Ulama Jepara \\ Jl. Taman Siswa (Pekeng) Tahunan Jepara 59427 \\ ${ }^{3}$ Program Studi Manajemen, Fakultas Ekonomi dan Bisnis, Universitas Islam Nahdlatul Ulama Jepara \\ Jl. Taman Siswa (Pekeng) Tahunan Jepara 59427 \\ ${ }^{4}$ Program Studi Ekonomi Islam, Fakultas Ekonomi dan Bisnis, Universitas Islam Nahdlatul Ulama Jepara \\ Jl. Taman Siswa (Pekeng) Tahunan Jepara 59427 \\ *Email: silvy@unisnu.ac.id
}

\begin{abstract}
Abstrak
Jepara merupakan salah satu daerah yang menjadi produsen arang kayu. Program pengabdian kepada masyarakt dengan skema Program Pengembangan Produk Ekspor (PPPE) ini bekerjasama dengan UMKM mitra yang memproduksi arang kayu yaitu Pirates dan Golden Black. Permintaan produk kedua UMKM mitra berasal dari Timur Tengah, Australia dan paling banyak dari Eropa. Namun permintaan dari negara-negara Eropa sering tidak terpenuhi karena berbagai kendala yang dihadapi mitra. Pada tahun pertama kedua mitra sudah diberikan alat produksi yang diharapkan dapat menambah kepasitas produksi berupa pembangunan tungku pembakaran arang. Akan tetapi kedua mitra juga belum bisa memenuhi semua permintaan karena masih adanya kendala dalam aspek produksi yaitu belum dimilikinya alat pengering yang dapat dioperasikan dalam segala cuaca dan memiliki kapasitas yang besar. Oleh karena itu pada tahun kedua program ini memberikan tambahan alat produksi berupa oven untuk proses pengeringan arang setelah melalui tahap pencetakan. Selanjutnya dilihat dari aspek manajemen, kedua UMKM belum memahami dan mengaplikasikan sistem administrasi perpajakan, oleh karena itu tim pengabdi memberikan pelatihan administrasi perpajakan. Diharapkan setelah dilaksanakannya program pengabdian pada tahun kedua ini, UMKM mitra dapat meningkatkan kapasitas produksi sehingga dapat memenuhi permintaan yang ada serta pemilik UMKM sadar akan pajak yang harus dibayarkan oleh setiap wajib pajak yang nantinya sebagai kontribusi dalam menciptakan keadilan dan peningkatan kesejahteraan masyarakat secara merata.
\end{abstract}

Kata Kunci : Arang Kayu, UMKM, Produk Ekspor, Jepara

\section{PENDAHULUAN}

Pertumbuhan ekonomi terutama di negara sedang berkembang seperti Indonesia, tidak dapat dilepaskan dari peran dan sumbangsih unit-unit usaha baik yang berskala mikro, kecil dan menengah atau sering disebut dengan UMKM. Pada awalnya sektor UMKM tidak dilirik oleh kalangan pengusaha bahkan pemerintah sekalipun. Akan tetapi setelah krisis ekonomi melanda Indonesia dan ternyata banyak sektor usaha terutama UMKM yang tetap bertahan serta mampu melanjutkan roda usahanya. Mulai saat itulah pemerintah lebih mengarahkan perhatian serta pembinaannya terhadap UMKM. Pemerintah berharap dengan dibangunnya sektor UMKM, maka ketahanan dan pertumbuhan ekonomi serta pembangunan ekonomi bangsa akan lebih mudah direalisasikan.

Salah satu jenis UMKM yang menjadi titik perhatian program pengabdian kepada masyarakat melalui Program Pengembangan Produk Ekspor (PPPE) ini adalah UMKM penghasil arang. Produk arang atau sering disebut dengan istilah 'black gold' (emas hitam) merupakan salah satu jenis produk penghasil devisa negara. Pasalnya produk arang sudah terbukti banyak dibutuhkan oleh pasar manca negara, seperti negara-negara di benua Asia, Australia bahkan Eropa. Hal ini dapat dibuktikan dari permintaan yang membanjiri UMKM mitra berasal dari negara-negara Timur Tengah, Australia dan bahkan permintaan terbanyak datang dari negara-negara Eropa. 
Komoditi arang dapat diproduksi dengan bahan baku berasal dari kayu, kulit kayu, serasah, serbuk gergaji, tempurung kelapa, serta sekam padi. Akan tetapi kedua UMKM mitra yakni "Pirates" dan "Golden Black" memproduksi arang dengan spesifikasi bahan baku kayu.

Secara garis besar dapat dijelaskan proses pembuatan arang kayu, dimulai dari proses pembakaran kayu yang dilakukan dengan menggunakan tungku pembakaran, dimana tim pengabdi sudah membuatkannya pada pelaksanaan pengabdian tahun pertama. Setelah kayu dibakar dan sudah berubah wujud menjadi bara, pada proses pemanenannya dilakukan dengan penyiraman air untuk memadamkan bara api sehingga arang yang dipanen dalam kondisi basah. Tahap selanjutnya adalah pengeringan sehingga arang kayu menjadi kering dan siap untuk dikemas. Sedangkan untuk produk arang dalam bentuk briket harus melalui tahap pencetakan terlebih dahulu kemudian dikeringkan. Proses pengeringan guna menghilangkan kandungan air dari arang maupun briket merupakan tahap penting yang harus dilakukan dengan efektif, karena kualitas produk ditentukan pada tahap tersebut.

Dalam proses pengeringan, sebelumnya mitra menggunakan metode penjemuran yaitu memanfaatkan sinar matahari sebagai sumber panas. Metode seperti ini selain menghasilkan produk dengan kualitas rendah karena kadar airnya masih tinggi, juga membutuhkan waktu produksi yang relatif lama sehingga proses pengeringan merupakan kendala yang dihadapi mitra dalam upaya memenuhi permintaan pelanggan. Guna mengatasi kendala tersebut, mitra sudah berupaya membuat oven untuk membantu mempercepat proses pengeringan arang dari tungku pembakaran maupun briket arang setelah keluar dari mesin pencetak. Akan tetapi oven yang dibuat mitra, hasilnya kurang maksimal serta kurang efisien dalam operasionalisasinya, karena untuk pemanasnya masih menggunakan kayu serta kapasitas oven yang kecil sehingga dalam satu kali proses produksi biaya yang dikeluarkan masih sangat tinggi.

\section{METODE}

Pelaksanaan kegiatan PPPE pada tahun kedua ini meliputi perencanaan, pelaksanaan, pelatihan hingga proses pendampingan dilakukan oleh tim pengabdi, meliputi:

1. Pembangunan Oven

Pembangunan oven dilakukan dengan tahapan kegiatan, pertama membuat rancang bangun dengan cara berkonsultasi dengan ahli meliputi bahan baku yang digunakan sampai dengan aspek teknis termasuk tingkat resiko penggunaan alat. Kemudian pada tahap selanjutnya dilakukan pembangunan atau perakitan oven yang dilakukan oleh ahli. Setelah oven siap untuk dioperasikan, tim pengabdi juga memberikan pelatihan penggunaan alat tersebut sehingga mitra dapat mengoperasikannya. Tahap pelatihan diakhiri ketika mitra sudah bisa mengoperasikan oven, akan tetapi tim pengabdi masih melaksanakan pendampingan karena dikhawatirkan mitra masih menemui kendala dalam operasionalisasi alat baru tersebut.

2. Pelatihan Perpajakan

Pelatihan perpajakan dimulai dari pelaksanaan sesi pelatihan administrasi pajak dengan narasumber ahli dalam bidang perpajakan. Pelatihan adminitrasi perpajakan dilakukan beberapa kali sehingga dipastikan mitra benar-benar memahami sistem pajak hingga alur yang harus dilalui dalam pengurusan adminitrasi perpajakan. Setelah dilakukan sesi pelatihan, tim pengabdi juga melakukan pendampingan terhadap mitra sehingga ketika program ini berakhir diharapkan mitra bisa menangani administrasi perpajakan secara mandiri.

\section{HASIL DAN PEMABAHASAN}

Kegiatan pengabdian dilaksanakan dengan hasil yang didapat dalam pengabdian ini adalah sebagai berikut:

\section{Pembangunan Oven}

Hasil yang dicapai dalam pembuatan oven adalah tersedianya oven yang dapat membantu mitra dalam upaya meningkatkan kapasitas produksinya. Manfaat yang dapat dirasakan mitra dengan dibangunnya oven baru ini, adalah keberlanjutan proses produksi yang tidak lagi terkendala oleh faktor alam. Oven bisa digunakan kapan saja tanpa memperhatikan cuaca seperti pada proses tradisional. Prodses produksi mitra yang dilakukan dengan oven baru diharapkan hasil yang optimal dan lebih menghemat waktu, sehingga dapat meningkatkan kapasitas produksi arang. Sesuai dengan 
metode pelaksanaan yang telah diuraikan, maka pembangunan oven dapat diwujudkan sesuai dengan rencana. Profil alat pengering arang (oven) dapat digambarkan sebagai berikut:

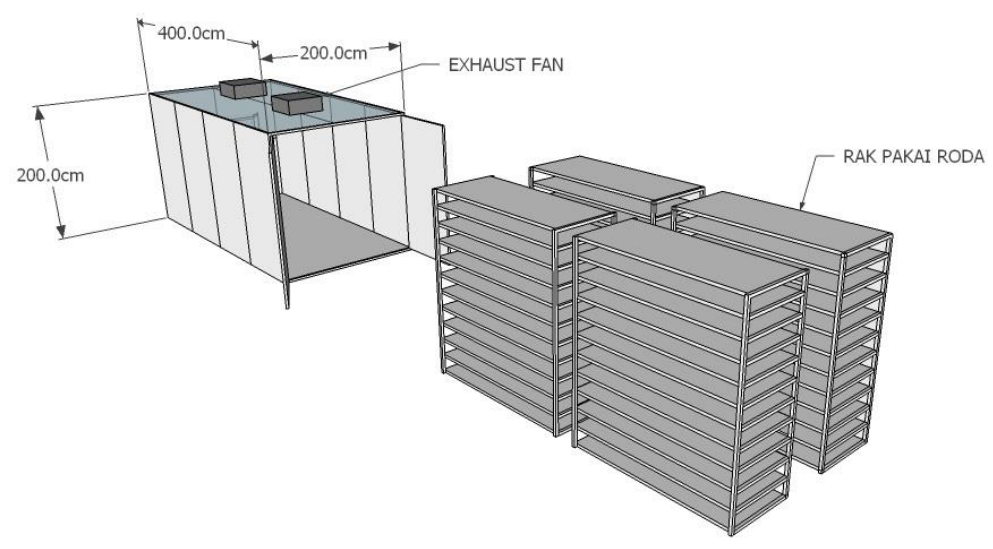

Gambar 1. Spesifikasi Rancangan Oven

Komponen utama pembuatan oven adalah galvalum, merupakan jenis bahan yang lebih tahan terhadap korosi atau karatan. Sedangkan rangka oven terbuat dari baja yang merupakan jenis logam yang lebih tahan terhadap panas. Dengan komposisi bahan-bahan tersebut, diharapkan oven akan dapat digunakan oleh mitra untuk jangka waktu yang lama.

Ukuran oven cukup luas yaitu $16 \mathrm{~m}^{3}$ dengan rincian: panjang 4 meter, lebar 2 meter dan tinggi 2 meter. Bagian dalam dibuat rak-rak untuk meletakkan arang ataupun briket yang akan dikeringkan sehingga proses pengeringan lebih efektif karena terdapat rongga-rongga untuk mempercepat pemerataan panas. Rak-rak tersebut dibuat sedemikian rupa sehingga mudah untuk ditarik keluar masuk oven guna memudahkan proses loading serta pemanenan setelah proses pengeringan selesai. Sumber panas yang digunakan pada oven adalah dua kompor gas yang diletakkan di bagian bawah.

Setelah pembangunan oven selesai dan sudah diserahterimakan kepada mitra, selanjutnya tim pengabdi menyelenggarakan pelatihan penggunaan oven terhadap sejumlah karyawan mitra. Pelatihan dilaksanakan sebanyak dua kali sehingga dipastikan karyawan bagian produksi khususnya yang diberikan tanggung jawab terhadap alat tersebut sudah dapat mengoperasikannya. Namun demikian, tim pengabdi tetap melaksanakan pendampingan penggunaan oven tersebut yang dilaksanakan selama kurun waktu satu bulan hingga dipastikan tidak muncul permasalahan atau kendala yang mungkin dihadapi mitra dengan adanya alat produksi baru tersebut. Dengan penambahan alat produksi oven tersebut diharapkan mitra akan dapat meningkatkan kapasitas produksinya sebesar $10 \%$, dengan demikian akan dapat meningkatkan omzet UMKM mitra.

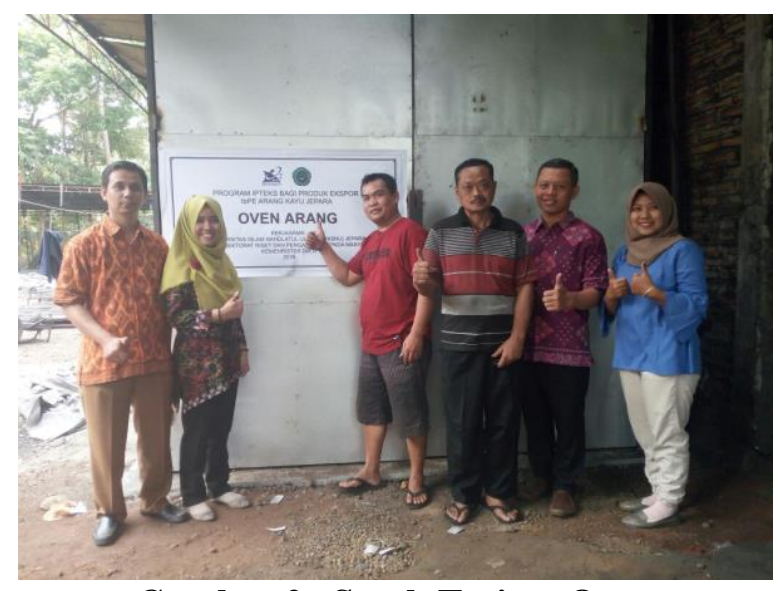

Gambar 2. Serah Terima Oven 


\section{Pelatihan Perpajakan}

Tim bekerjasma dengan tenaga ahli yaitu konsultan pajak dalam melakukan pelatihan perpajakan mengenai penghitungan pajak pada kedua mitra masing-masing dilaksanakan sebanyak dua hari. Peserta pelatihan adalah seluruh karyawan bagian administrasi yang diharapkan seluruh peserta memahami dan dapat melakukan administrasi perpajakan secara mandiri. Seusai pelatihan administrasi perpajakan selanjutnya dilakukan pendampingan mengenai penghitungan beban pajak yang ditanggung pada masing-masing mitra sesuai dengan peraturan pajak yang berlaku agar dalam penerapan nantinya mitra dapat menyelesaikan administrasi pajaknya sendiri.

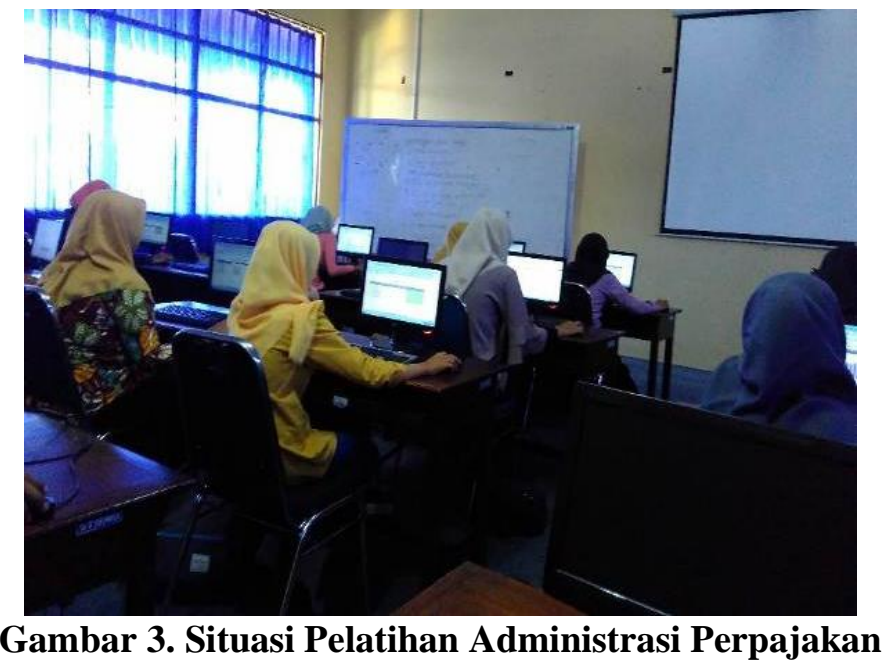

\section{KESIMPULAN}

Berdasarkan pelaksanaan Program Pengembangan Produk Ekspor yang diselenggarakan tim pengabdi, dapat diambil kesimpulan sebagai berikut:

1. Pembangunan alat pengering (oven) arang telah dilaksanakan yang selanjutnya menjadi tambahan aset bagi mitra, selain dapat meningkatkan kapasitas produksi sudah barang tentu akan meningkatkan omzet produksi mitra.

2. Tim pengabdi juga telah melakukan pelatihan dan pendampingan mengenai administrasi perpajakan hingga metode penghitungan beban pajak yang menjadi taggungan mitra sebagai wajib pajak dapat diterapkan dengan baik, sehingga program pengabdian ini secara tidak langsung mendukung program pemerintah dalam pemerataan pendapatan masyarakat untuk mewujudkan masyarakat yang adil dan makmur akan dapat terwujud.

3. Dengan demikian tujuan pelaksanaan program pengabdian kepada masyarakat dengan skema PPPE ini dapat terwujud yaitu ikut memberdayakan UMKM sebagai pilar ketahanan dan pertumbuhan ekonomi serta pembangunan ekonomi bangsa akan lebih mudah direalisasikan.

\section{UCAPAN TERIMAKASIH}

Tim pengabdi menyampaikan ucapan terima kasih kepada Kemenristekdikti yang telah mendukung penuh pelaksanaan kegiatan pengabdian kepada masyarakat melalui Program Pengembangan Produk Ekspor (PPPE) ini. Demikian juga terima kasih kepada LPPM UNISNU Jepara yang telah memfasilitasi dan mendampingi tim pengabdi mulai dari perencanaan, pelaksanaan hingga proses pelaporan kegiatan. Kepada UMKM mitra juga kami sampaikan terima kasih telah berperan aktif dalam pelaksanaan pengabdian serta sharing pendanaan yang telah dilakukan demi terlaksananya program ini, serta pihak-pihak terkait yang telah membantu hingga terlaksananya program pengabdian ini.

\section{DAFTAR PUSTAKA}

Ahmad Sanusi. 1974. Menelaah Potensi Perguruan Tinggi Untuk Membina Program Kewirausahaan dan Pengatar Pewirausaha Muda,Makalah Seminar. Bandung: KOPMA-IKIP 
Avlonitis, G. and Slavou, H. 2007. Entrepreneurial orientation of SMEs, product innovativeness, and performance., Journal of Business Research. vol. 60, pp. 566-575.

Hadi, Samsul. 2016. Teknologi Bahan. Yogyakarta: CV. Andi Offset.

Handoko, H. 2001.Manajemen Sumher Daya Manusia Dan Personalia. Yogyakarta: BPFE UGM.

Haryanto, Bambang. 2007. Kamus Teknik Lengkap. Surabaya: Serba Jaya.

Kaplan, Robert S, dan David P Norton. 2000 Balanced Scorecard : Menerapkan Strategi menjadi Aksi. Penerbit Erlangga. Jakarta.

Mangkunegara, A.P. 2001. Manajemen Sumber Daya Manusia Perusahaan Remaja Rosdakarya. Bandung.

Nawawi, H. 2002. Manajemen Sumber Daya Manusia Untuk Bisnis Yang Kompetitif. Yogyakarta: Gadjah Mada University Press.

Nitisemito, A. S. 2000. Manajemen Personalia. Jakarta: Ghalia Indonesia.

Robbins, Stephens P. 2001. Perilaku Organisasi, Edisi Indonesia. Jakarta: Indeks

Yustinus, Prastowo. 2009. Panduan Lengkap Pajak. Jakarta: Raih Asa Sukses.

Zain, Mohammad. 2007. Manajemen Perpajakan. Jakarta: Salemba Empat. 